Bank, L. J. \& Bank, A. (2013). Untangling the Lion's Tale: Violent masculinity and the ethics of biography in the 'Curious' case of the apartheid-era policeman Donald Card. Journal of

\title{
Untangling the lion's tale: Violent masculinity and the ethics of biography in the 'curious' case of the apartheid-era policeman Donald Card
}

\author{
Leslie J. Bank and Andrew Bank
}

\begin{abstract}
Donald Card (1928-) is a former policeman in South Africa who became the subject of international media attention on 21 September 2004. In a highly publicised and symbolic ceremony of reconciliation inaugurating the Nelson Mandela Centre of Memory Project, he handed back to Mandela two notebooks containing 78 hitherto unknown letters written by Mandela on Robben Island. A starkly contrasting image of Card as a torturer had, however, come to light during the Truth and Reconciliation Commission (TRC) hearings in the Eastern Cape in 1996 and 1997. This article begins by making a case for a direct connection between these two events. We argue that the sanitised version of his life history in recent scholarship traces back to his own attempts to defend his reputation from these allegations of torture and that the Mandela notebooks served both to obscure these allegations and provide Card with a respectable, even heroic, biography. We then present our alternative version of his life history. Drawing on Robert Morrell's periodisation of masculinities in southern Africa, we read the story of Card's life in earlymid-twentieth century South Africa in terms of changing masculine identities, each strongly associated with violence: first the 'oppositional' masculinity of a child growing up in an abusive patriarchal Irish settler family, second the 'settler' masculinity of an athletic teenager at a white school in the former Transkei, and third his 'hegemonic' white South African masculine identity defined in opposition to emergent black masculinities into which he was initiated as a young adult during four months of intensive training at a police college in Pretoria. It is in this context, along with extensive new independently acquired oral and documentary evidence of his human rights abuses in East London in the 1950 os and the early 1960s, that we situate the TRC testimonies about Card's torture between 1962 and 1964 .
\end{abstract}

[Y]our case, as you are perhaps now aware, has become one of the more curious cases ... for this Commission. The key question is, Who is Donald Card? What is the truth about that? ... [O]n the one hand, there is the picture of Donald Card the hero, a man who lays his life on the line, sacrificing all in order to take that fateful step of trying, of assisting Donald Woods into exile, Donald Card who we have to respect, to admire, to salute for tremendous courage. Then there is on the other hand, this other picture of Donald Card, if you can excuse my words, the monster who terrorised freedom fighters in this area [the Eastern Cape] . . . men who were trying to make a statement about the need for 
democracy in our country ... [who] were terrorised and placed under terrible conditions by that Donald Card ... As a Commission we have to come to an answer one way or another on that matter. - Chairperson, Truth and Reconciliation Commission Hearing, King William's Town, 14 May $1997^{1}$

We have learnt much about the politics of biography in South Africa in recent years, ${ }^{2}$ but what of the complex ethical issues involved in the writing of other people's life histories? How do biographers balance their responsibilities towards the subjects of their stories and the various audiences for whom they write who have expectations regarding authenticity?

The ethical bar is raised considerably when the biographical subjects are alleged to have committed gross violations of human rights and express varying degrees of willingness to share their darkest secrets in private or in public. For those willing to have their stories told, whether from fear of prosecution, out of a sense of guilt, or for other reasons, what are the moral issues involved in the sensitive series of negotiations with authors from their first interviews to the publication of an article or a book?3 Such ethical issues apply from the most high profile cases downwards. How, for example, do we weigh up the 'bargain of collaboration'4 between Jacques Pauw and former Vlakplaas commander and 'death squad' leader Dirk Coetzee, or that between Jeremy Gordin and Eugene de Kock who was found guilty of six counts of murder? In the former case this bargain involved the Vrye Weekblad journalist going to extraordinary lengths to guarantee the safety of Coetzee and his family in exchange for the 'scoop that every journalist and editor dream about' and one that 'would probably guarantee Vrye Weekblad's existence, safeguarding foreign funds for years to come'.5 In the latter case the bargain involved, at base, an exchange of secret and politically explosive information for the crafting of a rehabilitated public image?6

The ethical complexities are all the greater in those unusual instances where the 'perpetrator' has undergone a complete change in political ideology. This was the case

\footnotetext{
${ }^{1}$ Donald Card's Defence presented at Daniel Paulus Nongena and Makhi Boyi, TRC Hearing, King William's Town, 14 May 1997, Transcript, Case EC1985/96KWT, p. 13. When Card objected to being called a 'monster', the Chairperson replied: '[Laughs.] Ja, I regret perhaps, the use of that word. I was just trying to summarise the other picture that is portrayed in the statements before us. They portray the picture of a monster.' (Transcript, p. 14). We are grateful to Donald Card for identifying the chairperson cited above as the Reverend Bongani Finca, thereby correcting a naming error in the original draft of this article.

${ }^{2}$ See C.S. Rassool, 'The Individual, Auto/biography and History in South Africa' (Ph.D., University of the Western Cape, 2004); for recent debate, see C.S. Rassool, 'Rethinking Documentary History and South African Political Biography', South African Review of Sociology, 41 (2010), pp. 28-55; J. Hyslop, 'On Biography: A Response to Ciraj Rassool', South African Review of Sociology, 41 (2010), pp. 104-115.

${ }^{3}$ For an excellent self-reflexive study of the life histories of nine men who had committed human rights abuses during the apartheid period and the complex moral issues involved in the authors' interviewing of these subjects, see D. Foster, P. Haupt and M. de Beer, The Theatre of Violence: Narratives of Protagonists in the South African Conflict (Cape Town, HSRC Press, 2005), especially pp. 89-104.

${ }^{4}$ This concept was coined by Ronald Robinson in the 1960s and has been applied to the role of African intermediaries in colonial rule in nineteenth and twentieth century Africa. See B.N. Lawrance, E.L. Osborn and R.L. Roberts, 'Introduction: African Intermediaries and the "Bargain" of Collaboration', in Lawrance, Osborn and Roberts (eds), Intermediaries, Interpreters and Clerks: African Employees in the Making of Colonial Africa (Madison, University of Wisconsin Press, 2006), pp. 3-34.

${ }^{5}$ J. Pauw, In the Heart of the Whore: The Story of Apartheid's Death Squads (Johannesburg, Southern Book Publishers, 1991), p. 21.

${ }^{6}$ Gordin consistently portrays De Kock as 'merely a tool' or 'the proverbial fall-guy' of his superiors. He explicitly acknowledges that there was collaborative bargain involved: 'Given this kind of subject matter, given De Kock's behaviour, personally or by proxy, why was a decision taken to collaborate with the erstwhile colonel to bring out a book?' (He argues that it was in the public interest to find out about 'the men who pulled the strings'.) E. de Kock with J. Gordon, A Long Night's Damage: Working for the Apartheid State (Johannesburg, Contra Press, 1998), pp. 16, 22, 24, 30.
} 
with Donald Card, a central figure in the apartheid police force during the 1950 s and 1960 s who had a Damascus Road conversion in the 1970s. While the case of Card may not have the same international profile as that of Kurt Waldheim, 7 for example, the accusations against him are the more serious in that they involve allegations not just that he was complicit in human rights abuses by virtue of his association with the apartheid state, but that he himself took an active role in them.

At the centre of our investigation is an attempt to uncover, as the local TRC chairperson was keen to do, a more multi-faceted 'truth' about Donald Card, despite the embattled status of the concept? ${ }^{8}$ How and why, we ask, have historians and other stake-holders entered into 'bargains of collaboration' with Card in recent years that have allowed him to publicise a sanitised version of his life history? How might one construct an alternative and less complicit version of his biography, one that reads his life story forwards rather than backwards in time, one that reflects not only on his place as a symbol of reconciliation but also on his changing earlier identity as a violent boy who became a violent man?

The aim of this article then is to uncover the hidden layers of evidence in the 'curious' case of Donald Card and thereby reassess the narrative of Card's role in the political history of the Eastern Cape and apartheid policing. We provide a starkly contrasting narrative to that presented in Card's recent auto/biography Tangling the Lion's Tale: Donald Card, From Apartheid Era Cop to Crusader for Justice 9 as well as to the versions of his life story popularised in recent historical writing, albeit in more ambiguous terms..$^{10}$ The account we present is based on a careful re-reading of these published texts, documentary evidence published in the Daily Dispatch in the 1950s and Drum magazine in the early 1960s, transcripts of proceedings from one Cape Supreme Court trial from 1963 and medical records from another, a close re-examination of the evidence presented against him at the TRC hearings in 1996 and 1997, as well as extensive new oral evidence gathered by one of us (Leslie J. Bank) between August 2010 and December 2012 from more than a dozen political activists from liberation movements who did not present

\footnotetext{
${ }^{7}$ Kurt Waldheim, the former United Nations Secretary-General and Austrian President, was found to have been associated with atrocities in Bosnia during the Second World War while serving as an intelligence officer in the Nazi army. The hidden truth about Waldheim's past only came to light in 1986, over forty years after the War. Although there is no concrete proof that Waldheim committed war-time atrocities himself, he was closely associated with units that did. In his defence Waldheim argued that he had no choice but to join the German army because Austria was occupied by the Germans during the war. Robert Edwin Herzstein, the historian who exposed Waldheim in 1986, stated that the issue of his personal (guilt or) 'non-guilt should not be confused with innocence' since his involvement with military units that exterminated Slavs and Greek Jews 'make him at least morally complicit' (Quoted in The New York Times, 14 June 2007; see R.E. Herzstein, Waldheim: The Missing Years (New York, William Morrow and Company, 1988).

${ }^{8}$ Posel argues that the TRC distinguished between four different notions of truth in its final report: factual/forensic truth; personal/narrative truth; social/ 'dialogic' truth; healing/restorative truth. For a highly incisive critique of the TRC Report, Volumes 1-5, including this 'wobbly conceptual grid' of a 'rainbow of truths', see D. Posel, 'The TRC Report: What Kind of History? What Kind of Truth?', in D. Posel and G. Simpson (eds), Commissioning the Past: Understanding South Africa's Truth and Reconciliation Commission (Johannesburg, Wits University Press, 2002), pp. 147-72. For a robust critique of the Amnesty Commission, see M. Mamdani, 'Amnesty or Impunity? A Preliminary Critique of the Report of the Truth and Reconciliation Commission of South Africa (TRC)', Diacritics, 32, 3\&4 (2002), pp. 32-59.

${ }^{9}$ C. Thomas, Tangling the Lion's Tale: Donald Card, From Apartheid Era Cop to Crusader for Justice (East London, Donald Card, 22 Hazyridge, Gonubie, 2007).

${ }^{10}$ Nelson Mandela Centre of Memory and Commemoration, A Prisoner in the Garden: Opening Nelson Mandela's Prison Archive (Johannesburg, Penguin, 2005), pp. 96-117.
} 
evidence before the TRC. ${ }^{11}$ Our alternative life history turns on a reading of his biography in relation to the concepts of race, masculinity and violence in southern African history.

The Re-invention of Donald Card, 1997-2007 Donald Card made a systematic attempt to rewrite his life history during the 1990s, building on a process that can be traced back to the time of his political change of heart. ${ }^{12} \mathrm{He}$ typed up a full autobiographical manuscript ${ }^{13}$ and drew on this in the account he gave of himself to the TRC in May 1997. Card had been accused of gross human rights violations in a series of earlier testimonies which will be discussed later. ${ }^{14}$ When he appeared in person for the first and only time before the Commission, he explained that he was motivated to tell his side of the story by an inner discomfort. 'I'm going through pain ... . [I want to] try and look for peace'. He began by denying that he had ever seen his accusers. ${ }^{15}$ 'I am not the person . . . and the Lord knows that as well.' He did admit, however, that at the age of 69 his memory as no longer entirely reliable. 'Unfortunately, the memory side is a little bit faded, even names now ... names have become impossible. I sometimes, I see a face and I think who is that and ten minutes after I'll remember who that person is but really my memory isn't so good anymore and I wouldn't remember most faces.' This stood in stark contrast to his memory in his former days as a Security Policeman when his ability to recall names and residential locations across an entire township (Duncan Village in East London) led his adversaries to nickname him 'Card-index'. ${ }^{16}$

Most of Card's testimony constructed an alternative image to that already presented before the TRC. At its centre was the story of the dedicated and law-abiding detective. Card began by explaining that he had been forced into policing by poverty.

\footnotetext{
${ }^{11}$ In all of these interviews the informants knew and agreed that their testimony would be used in this article, and indicated that they would be willing to verify their testimony in court if necessary. In all cases they agreed to be videoed and DVDs of these recordings are available from the Fort Hare Institute of Social and Economic Research. These videos and their transcripts are being deposited in the National Liberation Archives at the University of Fort Hare. All the extracts cited in this article have been fully transcribed from the original. The interviews were either in English or in Xhosa. In all cases Leslie J. Bank was the primary inverviewer. He was assisted in the case of interviews with ANC veterans by Koko Qebeyi and in the case of interviews with PAC veterans by Ndimphiwe Mkuzo. For reasons of space only the primary interviewer's name has been recorded in the references that follow. Transcribed translations from Xhosa to English were done throughout by Nomatshetshi Matolweni. We are most grateful for their committed assistance over an extended period.

${ }^{12}$ In an almost verbatim transcription of a lengthy interview with the Daily Dispatch journalist Barbara Hutmacher in the mid1970s, Card cast himself as a righteous and hard-working state policeman operating within the law to uphold justice and keep at bay the illegal forces attempting to destabilise the state. Card also speaks here of his subsequent change of heart and his close friendship with anti-apartheid journalist and editor Donald Woods. See B. Hutmacher, In Black and White: Voices of Apartheid (London, Junction Books, 1980), pp. 159-67.

${ }^{13}$ C. Thomas, 'Bloodier than Black and White: Liberation History seen through Detective Sergeant Donald Card's Narrative of his Investigations of Congo and Poqo Activities, 1960-1965', New Contree, 50 (November 2005).

${ }^{14}$ Public accusations of human rights violations against Donald Card predated these TRC testimonies. In 1995 the prominent ANC leader Steve Tshwete, one of Card's former victims, questioned the appropriateness of Card's presence at an ANC funeral in Chalumna. Tshwete raised the same issue at the ceremonial reburial of Washington Bongco in Fort Beaufort in 1998 as Card was among the prime agents responsible for having Bongco

sent to the gallows in 1964 on a charge of plotting against the apartheid state.

${ }^{15}$ Psychologist Don Foster demonstrates that denial was the overwhelming response of 'perpetrators' who testified before the TRC. The Amnesty Commission heard testimonies from just 293 applicants from the apartheid state (229 of them from the Security Police), whereas the Human Rights Violations Committee heard of 38,000 incidents described in over 22,000 'victim' testimonies. Out of a sample of fifty potential interviewees

approached by Foster, Haupt and De Beer between 2000 and 2004 for a more detailed exploration of their life narratives (see note 3 above), only one provided what Foster considered full acknowledgement of wrong-doing and full acceptance of its implications. See D. Foster, 'Confessions, Apologies and Perpetrators', in P. Gobodo-Madikizela and C. van der Merwe (eds), Memory, Narrative and Forgiveness: Perspectives on the Unfinished Journeys into the Past (Newcastle, Cambridge Scholars Publishing, 2009), pp. 170-87.

${ }^{16}$ On Card's nickname and remarkable powers of recall, see the account of the instructing attorney who represented Nelson Mandela and his co-accused at the Rivonia trial, in J. Joffe, The Rivonia Story (Cape Town, Mayibuye Books, University of the Western Cape, 1995), pp. 114-15.
} 
'You must realise, Mr. Chairman, it was shortly after the war, 1946, my father was poor. I couldn't go to university. I had to go and look for a job. If I wasn't a returned soldier, I didn't get a job.' In these straitened circumstances, 'I joined the Police Force in 1947 [at the age of nineteen]. In 1949 I became a detective and my duties as a policeman was [sic] to keep law and order in this country, in accordance with the existing laws. At no time did I consider that I should not take steps against those who broke the law . . ' He began his career in East London, but had influence on a national scale by the mid-1960s. With regard to where I was in '66, I think, let me start off by saying that . . I was, I am, a Xhosa linguist. I was sent by the Commissioner of Police to various places throughout the country, and I must say, that I think I was successful with regard to the cases I handled. I handled cases in Port Elizabeth ... in Cape Town, in Durban, Pretoria and Johannesburg. I was very well known among the political people in this country. In fact I also gave testimony in the Rivonia Trial ...

He did not mention, understandably, that his testimony had been part of the reason that Nelson Mandela and his co-accused were sentenced to life imprisonment. ${ }^{1717} \mathrm{He}$ then put on record numerous other details from his later life that bore witness not only to his public respectability but also to his transformation into an ardent opponent of apartheid during the 1970s, 1980s and 1990s. 'I was the Mayor of East London. I got the Freedom of the City of East London [in 1995]. I've been in the eyes of a lot of people for a long time.' He also had it put on record that he had been a member of the historic delegation that visited the ANC in Lusaka in 1989. He noted that he was a member of the Progressive Federal Party at the time. ${ }^{18}$

His public appearance before the TRC came after he had been granted amnesty by it the previous month. He had applied for amnesty, not for the allegations of torture mentioned by his accusers but for 'assisting a person banned in terms of the security legislation [Donald Woods] to break his banning order' and 'assisting the same person to leave the borders of South Africa in contravention of the law'.19 It is difficult to avoid the conclusion that his amnesty application was a pre-emptive measure designed to secure protection in the event that the torture charges against him were supported by the Commission. ${ }^{20}$

He wanted to ensure that his alternative history and self-image became part of the public record; and his strategy was successful. In the case of three of the accusations of torture, the first official TRC Report (October 1998, Volumes 1-5) recorded his denial - as it was legally bound to do. However, the names of all six witnesses (in one case the brother of a witness) who had accused him of torture were listed in the full inventory published as Volume 7 Victim's Findings, as a record with summary cases of all of 'those people found by the Commission to have suffered a gross violation of human rights'. ${ }^{21}$ The difficulties of

\footnotetext{
${ }^{17}$ Nelson Mandela Centre of Memory and Commemoration, A Prisoner in the Garden: Opening Nelson Mandela's Prison Archive (Johannesburg, Penguin, 2005), p. 110.

${ }^{18}$ The quotes above are drawn from Donald Card's testimony in his defence presented at Daniel Paulus Nongena and Makhi Boyi, TRC Hearing, King William's Town, 14 May 1997, Transcript, pp. 6-15.

${ }^{19}$ Donald Card's TRC testimony, Transcript, p. 11.

${ }^{20}$ This is confirmed by the account given in C. Thomas, Tangling the Lion's Tale: Donald Card, From Apartheid Era Cop to Crusader for Justice (East London, Donald Card, 22 Hazyridge, Gonubie, 2007), p. 242.

${ }^{21}$ TRC Report, vol. 3, pp. 39-40; TRC Report, vol. 7, Part 2, pp. 38-39, 143-4, 166; Part 3, p. 318, Part 4, p. 675, Part 5, p. 895.
} 
weighing up the potentially contradictory testimonies of 'victims' and 'perpetrators' in the quest for 'truth' have been addressed by many of the scholars writing about the Commission.

Deborah Posel argues that one of the main weaknesses of the Commission was that it had no clear guidelines for assessing how to weigh the conflicting evidence of the different forms of truth that it set out to establish, notably those 'factual and forensic truths' that they sought in relation to amnesty applications by 'perpetrators' and those 'personal and experiential truths' revealed in the testimony of 'victims'. ${ }^{22}$

Card, as is now common knowledge, had an unusual bargaining chip up his sleeve: two black notebooks containing 78 draft letters written by Nelson Mandela on Robben Island between 1969 and 1971. They had inadvertently come into his possession after his retirement from his later job as 'decoder' of prisoner letters in his last years working for the Security Police. In our view, these notebooks played a significant role in his efforts to bargain for a reformed life history.

The timing of the return of the notebooks is significant. They had remained in Card's possession for some twenty years without any attempts on his part to return them. Card claims that he tried to contact Winnie Mandela in 1990 and then Nelson Mandela's lawyers. Whatever the case, the process of negotiation only really got underway after the damage to his reputation caused by the TRC hearings in 1996-97. Cornelius Thomas, then Director of the National Heritage and Cultural Studies Centre at the University of Fort Hare in Alice, heard about the notebooks in 2002 and contacted Card. Thomas became Card's intermediary in the handover of the notebooks to the Nelson Mandela Centre and was entrusted with the task of authenticating the notebooks. He also, significantly, became Card's biographer. The early interviews for the book and their negotiations about the notebooks date to 2002. Both parties would have been aware of the value of Card's possession of the notebooks at a time when an enormous heritage industry was developing around the figure of Nelson Mandela.

Heroically subtitled From Apartheid Era Cop to Crusader for Justice, Cornelius Thomas's biography covers 256 pages. ${ }^{23}$ It is better read as an auto/biography co-authored by Thomas and Card. ${ }^{24}$ This version of his life history expands on the abbreviated account Card gave of himself to the TRC. Here the Card family history is presented in terms of a romanticised narrative about hardworking, morally upright white immigrants. The Cards are identified as the 'poor but honest' early mid-twentieth-century South African frontier equivalents of 'the Okies from Oklahoma, whom John Steinbeck immortalised in his novel The Grapes of Wrath'.25 Young Don grows up in the Transkei. He learns Xhosa and herds cattle, almost a white version of Nelson Mandela and, in fact, the parallel is

\footnotetext{
${ }^{22}$ Posel, 'The TRC Report. What Kind of History? What Kind of Truth?', pp. 147-72.

${ }^{23}$ C. Thomas, Tangling the Lion's Tale: Donald Card, From Apartheid Era Cop to Crusader for Justice (East London, Donald Card, 22 Hazyridge, Gonubie, 2007). The publication was self-funded. The main title conveys the sense that the life story of 'The Lion' (Card) is more complex than has been represented by his detractors.

${ }^{24}$ Given the closeness of the working relationship between Thomas and Card, this book straddles the boundary between biography and autobiography. The information is drawn overwhelmingly from Thomas's interviews with Card and from Card's own archive of documents and photographs. It is also significant that the book was published by Card himself.

${ }^{25}$ Thomas, Tangling the Lion's Tale, p. 13.
} 
explicitly drawn. ${ }^{26}$ Don was taught sound morals. In a highly symbolic incident we read of how his English mother forced her son to return a pen he had found on the street to the place where he had found it because it was 'dishonest to take another's property'. ${ }^{27}$

Card is presented here as having been apolitical at the time he joined the South African police force in $1947,{ }^{28}$ but possessed of these principles of decency and respect. His politics is alleged to have changed only in reaction to his encounter with the most brutal form of African political violence in the year of the Defiance Campaign. In November 1952 he was given the task of tracking down the township youths who burnt and then ate the body of Sister Aidan Quinlan, a white Catholic nun in Duncan Village. From then on Card served the community as a man who put his considerable detective skills to the defence of the value of righteousness, tracking down violent criminals who were disrupting society. These criminals included those ANC and PAC saboteurs of the early to mid-1960s whose stories are seldom told in liberation narratives. It was particularly in Card's revelations of the dark side of the anti-apartheid movement that Thomas saw his biography, and two articles that he had published in the course of its production, as 'offer[ing] some of the detail required for a new assessment of the liberation struggle in South Africa'.29 While one welcomes his complication of standard liberation narratives, the way in which he presents Card as a law-abiding detective is, as we shall see, open to question.

The ethical issues involved in the exchanges between Donald Card and the Nelson Mandela Centre for Memory and Commemoration Project are also complex. While the behind-the-scenes process of negotiation and acquisition would be interesting to chart with Thomas acting as the broker - our interest here is in the biographical redemption of Donald Card and, as such, in the version of his life story presented in the Centre's popular publication, A Prisoner in the Garden: Opening Nelson Mandela's Prison Archive published by Penguin in 2005, which had a much wider circulation than Thomas's subsequent biography.

'An Unlocking of Story: The Archival Threads Connecting Two Old Men' is the title of Chapter 3 of A Prisoner in the Garden. The old men in question are Nelson Mandela and Donald Card. There are two dominant images of Card that structure this account, both of which are consistent with the Thomas-Card auto/biography discussed above. The first is of Donald Card as a symbol of reconciliation. The notebooks containing the Mandela letters were the first acquisitions of the newly created Nelson Mandela Centre for Memory and Commemoration, the centre-piece of its internationally publicised launch ceremony on 21 September 2004. The chapter opens by citing Mandela's speech in which he thanks Card for returning the letters and commends him for 'his contribution to restoration and reconciliation', noting that Card might instead have 'decided to destroy the notebooks, or sell them to a wealthy collector'. The text endorses Mandela's image of Card as reconciler.

\footnotetext{
${ }^{26}$ Ibid., pp. 13 \& 62.

${ }^{27}$ Ibid., p. 14.

${ }^{28}$ Ibid., p. 22.

${ }^{29}$ Ibid., pp. 5, 3; C. Thomas, 'Bloodier than Black and White: Liberation History seen through Detective Sergeant Donald Card's Narrative of his Investigations of Congo and Poqo Activities, 1960-1965', New Contree, 50 (November 2005); C. Thomas, 'The Entwined Tale of Inkie Hoyi, Washington Bongco, Donald Card and a "Core Group" of MK Operatives - A Foray into Political Violence and Intimidation in Duncan Village, 1959-1964', Journal of Contemporary History, 30, 1 (2005), pp. 156-77.
} 
'In restoring the books to their author, the other old man set right a past wrong.' Having identified some of the riches revealed in the 78 letters written by Mandela in the period between April 1969 and April 1971, the chapter goes on to address Card's life story more directly in a subsection headed 'The other old man ... '. A full-page picture of a smiling Donald Card opening the notebooks to their title page features alongside with the caption: 'Former security policeman Donald Card with the notebooks he returned to Mandela in 2004'.

Card is now given the opportunity of introducing himself in the form of a highly abbreviated CV that he presented to the Master of Ceremonies. '1947: Joined the South African Police; 1964: Became a member of the Security Police; 1970: Became frustrated and resigned from the Police'. The implication is that his Security Police activities were a relatively brief and uncomfortable phase in his longer history of service. Card's speech at the event is then cited almost in full. In it he explains how the notebooks had come into his possession by mistake, having been posted to him after his resignation from his job as 'decoder' of letters from the Island in 1969 and 1970. A photograph on the following page, donated by Card, is captioned: 'Donald Card's house in East London where Mandela's notebooks were held'. He also makes the claim that he had long tried to return them. The image of Card as symbol of reconciliation is also visually reinforced by the final photograph showing 'Ahmed Kathrada (left), Mandela and Donald Card with the Centre of Memory Project team at the Nelson Mandela Foundation, September 2004'.

The second image is that of Donald Card as an 'archival enigma', a still unsolved mystery. It is only now, near the end of the chapter, that we are presented with the evidence of Donald Card the 'monster' of the TRC chairperson's terminology. We learn here in some detail about his earlier testimony against Nelson Mandela and his co-accused at the Rivonia Trial and of the allegations of torture that were brought against him at the TRC in 1996 and 1997, but these are seemingly counter-balanced by his own alternative narrative that highlights his three terms as mayor of East London, his visit to Lusaka to meet with the ANC in exile and his later work in transitional government in East London, as well as his brave support of his close friend Donald Woods. In the end the scholars tasked with writing this chapter are reluctant to do anything more than offer what they term 'multiple interpretations', 'a complex knot of threads'. They conclude:

The archival threads around Donald Card are very knotted indeed. The archive laid down in the pages of the Daily Dispatch, in the TRC process, and in the countless memories that survive, enters into an enigmatic dialogue with the Rivonia Trial transcript almost forty years earlier, and the handover ceremony at the Nelson Mandela Foundation in 2004. The glimpses of the records produced here give us a taste of the many interpretations they afford ... 30

Was there not a 'bargain of collaboration' involved here? Were the authors of the chapter not obliged to construct such an image of Donald Card as reconciler in return for the donation of the treasured notebooks? One might ask more provocatively whether a

\footnotetext{
${ }^{30}$ Nelson Mandela Centre of Memory and Commemoration, A Prisoner in the Garden, p. 116; all other quotes cited above are taken from chapter 3, pp. 97-119. The text identifies Carolyn Hamilton, Verne Harris, Mac Maharaj and Anthea Josias as the writing team.
} 
reading of 'multiple interpretations' and 'archival knots' is not a disavowal of the responsibility of the historian to provide adequate and rigorous assessment of the case based on the evidence as a whole? Does the assumption that there is not a single truth which few would dispute in our post-positivist age - not slide here too easily into a disavowal of the social responsibility on the part of scholars to provide their audience (here a wide popular as well as a scholarly readership) with proper guidance as to the pattern of violence and the powerful case for torture that Card's accusers provide when read collectively.

The Making of a Violent Man, 1928-1952 It is time now to turn attention to our own version of Donald Card's life story. In a seminal article published in JSAS in 1998, Robert Morrell set out a persuasive case for applying an international literature on masculinities to southern African history in what he identifies as part of what Nancy Rose Hunt described as a 'third wave' of research into gender studies in Africa. ${ }^{11}$ Morrell outlines a theoretical approach towards the study of masculinity that emphasises its socially constructed, fluid nature, and that moves away from thinking in terms of a singular masculinity to thinking about different forms of masculinities that are contested and historically changing. He argues for the utility of Bob (Raewyn) Connell's concept of a 'hegemonic masculinity', a dominant form of masculine power and authority that is held in place by consensus for the most part, but that is always underpinned by the threat and sometimes the overt exercise of physical violence, ${ }^{2}$ noting that violence is the one aspect of the history of masculinities in the region that had hitherto received some scholarly attention. 33

Most importantly, he makes an exploratory case for thinking about the emergence and development of different forms of masculinity in southern Africa between the late nineteenth and the mid-twentieth century. In his overview, a 'hegemonic' British imperial form of masculinity was challenged by 'oppositional' Afrikaner nationalist masculinities between the 1920 s and the 1940 s with an associated shift in state power. There remained a colonial frontier (English) 'settler masculinity', which he had explored in his earlier writings on colonial Natal.34 With the coming of apartheid, but with roots going back to Afrikaner-English mobilisation in the Great War, there emerged a new 'hegemonic' white South African masculinity. This white South African masculinity defined itself decisively in opposition to a 'black masculinity' of the 1940s and 1950s rather than to the older and more traditional 'African' masculinities. This new 'black masculinity' was urban, assertive, forward-looking and highly politicised. 35

While masculinities are collective social identities, they also (as Morrell explains in another seminal article) have application to individual life histories. ${ }^{6}$ Let us turn then to the specific details of Card's upbringing and his early induction into the kind of white

\footnotetext{
${ }^{31}$ R. Morrell, 'Of Boys and Men: Masculinity and Gender in Southern African Studies', Journal of Southern African Studies (JSAS): Special Issue on Masculinities in Southern Africa, 24, 4 (December 1998), pp. 605-630; N. Rose Hunt, 'Introduction', Gender and History, 8, 3 (1996).

${ }_{32}$ Morrell, 'Of Boys and Men', pp. 607-8; R.W. Connell, Masculinities (Cambridge, Polity Press, 1996).

${ }^{33}$ See W. Beinart, 'Political and Collective Violence in South African Historiography', JSAS, 18, 3 (1992).

${ }^{34}$ See R. Morrell, From Boys to Men: Settler Masculinity in Colonial Natal, 1880-1920 (Pretoria, Unisa Press, 2001).

${ }^{35}$ Morrell, 'Of Boys and Men', pp. 614-26.

${ }^{36}$ R. Morrell, 'The Times of Change: Men and Masculinity in South Africa', in R. Morrell (ed.), Changing Men in Southern Africa (London, New York and Pietermaritzburg, Zed Books and University of Natal Press, 2001), pp. 3-40.
} 
settler masculinity outlined by Morrell. We do this by reading against the grain the rich evidence presented in the Thomas/Card auto/biography.

Donald Card was born at Port St John's in the former Transkei in 1928. His father was a poor Irish immigrant who struggled as a farmer for many years before taking up a supervisory job with the Butterworth municipality. While the emphasis in Thomas's biography is on Card's morally upright English mother, we see his life shaped as deeply by his violent Irish father. In an excellent recent book on Irish bandits in South Africa, Charles van Onselen writes that post-famine Irish families were marooned in an impoverished countryside and essentially had four options: they could join the priesthood, enter the British colonial army, emigrate to America, or insert themselves at the bottom end of the English working class in cities like Manchester. Most of the Irish in South Africa had taken the British army option which landed them on the Eastern Cape frontier or fighting Zulu wars in Natal. With the discovery of gold, many deserted the army and flocked to the Witwatersrand. In the countryside, van Onselen notes, many Irish deserters formed groups of rural brigands and became 'deeply anti-social violent men, members of a masculine cult capable of heinous crimes, [who were] unable to relate to women in meaningful ways'. $37 \mathrm{He}$ asserts that many of these men were prone to violence because of their experience in the army and the strong cultural emphasis on male bonding rites. In the South African countryside, 'unruly-boysturned- anarchic-young men' turned the cult of Irish masculinity into lived reality in various ways. 38

While Donald Card's paternal grandfather Cornelius immigrated to South Africa from the area around Limerick only in the early 1890s, he was from an impoverished peasant family that shared the rugged rural identity described by van Onselen. Card's father, Alfred John, was born in South Africa in 1900. The terms in which Thomas describes Alfred Card's behaviour towards his wife in Donald's pre-teen years, 39 before Alfred went off to the army, suggest that his father was sometimes aggressive and that marital relations within his home were not always harmonious. By Thomas's admission, Alfred Card was a hard nut with a 'Jekyll and Hyde' personality. He drank heavily and smoked a pack of 30 cigarettes a day; he was prone to 'tirades' and aggressive arguments that often reduced his wife to tears. Donald recalls that 'A dirty feel and a choking smell strangled their home'. As Jonathan Hyslop puts it in an intriguing exploration of his own family history and the transmission of trauma, '[i]n colonial patriarchies, fearful men produced fearful families'.40

Unlike the children in many other white frontier colonial families, Donald Card was not sent to boarding school. At a time when his father was drawn into the civil service and was setting up his own dairy, allowing him to make ends meet for the first time, young Donald was sent to the local white high school. Here he exchanged cow-herding for a rugby jersey

\footnotetext{
${ }^{37}$ C. van Onselen, Masked Raiders: Irish Banditry in Southern Africa, 1880-1899 (Cape Town, Zebra Press, 2010), p. 233. Van Onselen's social histories offer a body of work rich in explorations of 'oppositional masculinities', including those of Ninevite gangs, mine workers, Afrikaner and African peasant farmers, a violent man of an international underworld and Irish bandits.

${ }^{38}$ Van Onselen, Masked Raiders, p. 15.

${ }^{39}$ Alfred Card spent six years in the army during the Second World War when Donald was in his teens. Interview Koko QebeyiDonald Card, East London, 25 January 2012.

${ }^{40}$ J. Hyslop, 'Jandamarra, My Great-Grandfather and the British Empire: Reflections on Family History, Colonial War, and the Making of Men and Women', in L. Ouzgane and R. Morrell (eds), African Masculinities: Men in Africa from the Late Nineteenth Century to the Present (New York, Palgrave Macmillan, 2005), p. 142.
} 
and boxing gloves. He was a man of action rather an intellectual, one who was not averse to solving his problems with his fists. In these years at Butterworth High School between 1942 and 1946 (when he matriculated), we think of Donald Card as taking on a distinctively white (frontier) settler masculine identity, one that was rather more respectable than the 'oppositional' Irish masculine identity of his father and grandfather. Morrell has highlighted the role of schooling in the making of colonial settler identity in Natal. The influences he identifies are all evident in the case of Card's education at Butterworth High. The school cadet corps, for example, would have done very much more than instil 'discipline extraordinaire' (as Thomas suggests). It would have played a crucial role in creating a sense of white male racial pride and identification with the military and the nation. The role of rugby in the making of colonial masculinities has been well documented in the wider literature on the British empire and the stories of the 'tall and muscularly lean' teenage Donald's exploits in the First XV playing on the opposite flank from the later Springbok rugby captain (Basil Kenyon) are of a piece with these accounts. ${ }^{41}$ 'The 30 burly white men mercilessly tackl[ing] one another', Thomas suggests, was 'muscular Christianity at its best'. 42

Significantly for his later policing activities, there is strong evidence to suggest that Donald Card had become deeply racist in his outlook by the mid-1940s in ways that went beyond what one might term the 'normative everyday racism' of white settler society. During his years at Butterworth High he was involved in at least two incidents of racial assault. In one case he beat up a black man who was working for his father simply on the grounds that the man was 'being lazy'. A charge was laid at the local police station, but Card talked his way out of it. On another occasion his 'autobiographical notes' describe what we read as a symbolic illustration of violent confrontation between white settler masculinity and the new black masculinity of the 1940s.

At first these [Fort Hare] students [back home in Butterworth on vacation] were friendly and often spoke to us, but later on I got the impression that they were becoming arrogant and did as they pleased ... Both groups [the students and Card's own group of schoolmates] walked towards each other [along a pavement] and the Fort Hare students were obviously not going to give way for us to pass. This meant that we would have to walk around them, leave the pavement and go into the street. That could not be ... I told the rest of my group to walk with me and I would go through the centre of their line. I selected the biggest of their group and pushed my way through . . 43

The confrontation led to a fierce fight. Card needed stitches to his face and had cracked ribs. It is not difficult to imagine that following an incident like this, his already deep sense of white racial superiority began to give way to a sense of racial hostility towards blacks. It is significant that the target in this case were Fort Hare students, Africans who were better educated than Card and willing to challenge his sense of racial entitlement. They posed a threat to his masculinity by breaking the mould of colonial and frontier stereotypes of Africans as uneducated and servile.

\footnotetext{
${ }^{41}$ See J. Nauright and T. Chandler (eds), Making Men: Rugby and Masculine Identity in the British Isles and Settler Empire (London, Frank Cass, 1996).

${ }^{42}$ Thomas, Tangling the Lion's Tale, pp. 15-16.

${ }^{43}$ Ibid., pp. 27-28.
} 
Donald Card's identity as a domineering white teenager willing to use violence to assert his power over blacks was doubtless reinforced rather than challenged by his experience of working as a mine surveyor in Johannesburg for some months in 1947.44 A bout of pneumonia forced him to return home after less than a year and a local police sergeant persuaded him to join the force instead. It was during four months of intensive training with 'his beloved Troop 6' at Police College in Pretoria West in late 1947 that we see Card experiencing his real initiation into a more inclusive white South African masculine identity. Descriptions of male bonding rituals loom large in the Thomas/Card auto/biography. His fellow troopers were a mixture of Afrikaners and Englishmen, though the drill sergeants were mainly Afrikaners, men with evocative nicknames like 'Bokkie' Breedt, 'Donker Afrika' Botha (who was of a suntanned complexion) and 'Piel Vingers' du Plessis (who owed his unusual nickname to 'his abnormally large fingers which resembled the size of a man's penis and which he had apparently got from frostbite during the war of 1939-45').45

If it was in Pretoria that Card was inducted into a 'hegemonic' white South African masculine identity, it was in the early apartheid years as a policeman in East London that this identity was reinforced. Here again his workmates were a mix of English and Afrikaner: Jack Forster, Peter Nicholson and Sarge Wheeler, on the one hand, Pretorius, Constable Swannie Swanepoel and JC 'Ridgeback' de Villiers, on the other. Keith Shear indicates that all officers and two-thirds of the rank-and-file of the South African police force were white throughout the period between 1910 and 1939.46 Although Shear suggests that black-white ratios were somewhat more equal from the late 1940s onwards, whites continued to dominate the force. As at school, sport served as a prime male bonding ritual for young policemen, though now it was athletics rather than rugby at which he most excelled. Card represented the whites-only Police Athletics Team in his early years on the force, becoming the Border and Eastern Cape champion for the 440 and 880 yards races. At a time when the Afrikaner component of the civil service and the police force in East London increased markedly, Card was known to his colleagues as 'Die Engelsman'.47

\section{Card's Methods of Policing, 1952-59}

While the TRC only heard cases from 1960 onwards, the evidence of Donald Card's violations of human rights may be traced back to 1953. Card was appointed as a senior investigator for the Sister Aidan murder case mentioned above. The reason for his selection had to do with his competence in Xhosa and his familiarity with East Bank location where he had immersed himself since his arrival in the city. The mob killing of the white nun and an innocent insurance salesman, who was also chased and beaten to death by a group of youths, during the November 1952 political violence in East Bank

\footnotetext{
${ }^{44}$ See K. Breckenridge, 'The Allure of Violence: Men, Race and Masculinity on the South African Gold Mines, 1900-1950', Journal of Southern African Studies, Special Issue on Masculinities in Southern Africa, 24, 4 (December 1998), pp. 605-30.

${ }^{45}$ Thomas, Tangling the Lion's Tale, p. 28.

${ }^{46}$ For a discussion of the way that the minority of black policemen were discriminated against institutionally and socially, and perceived with great hostility by other Africans, in South Africa between 1910 and 1939, see K. Shear, "Taken as Boys": The Politics of Black Police Employment and Experience in Early Twentieth- Century South Africa', in L.A. Lindsay and S.F. Miescher (eds), Men and Masculinities in Modern Africa (Portsmouth, NH, Heineman, 2003).

${ }^{47}$ Thomas, Tangling the Lion's Tale, p. 25.
} 
created shock and hysteria within the East London white community. The manner of the nun's death provoked fears of Mau Mau-style murders spreading through the city. 4848 The day after the riot, press reports were written of cars been stoned on roads around the city. In this context, the police showed no mercy in rounding up political youths. Arrests were rough and violent as suspects filled city goals. The Duncan Village African National Congress leader, J.J. Matotie, was picked up in the location in November 1952. He wrote to a letter to the Daily Dispatch newspaper after his release in February 1953:

I was arrested on November 14, 1952, on a charge of an alleged contravention of the Suppression of Communism Act and locked up in Lock Street Jail. I was standing looking when a member of the CID who had escorted me to the jail spoke to the European warder. Another warder came towards me and hit me hard on the chest with his fist. I had not said a word to this warder; nor did I know of any offence committed by me. No one seemed to be surprised by this act; nor was the warder rebuked by the CID officer who saw this unprovoked assault. For allegedly talking on the parade line on the 15th November an African youth was struck by a high ranking prison officer. The blows appeared to be far in excess of those necessary to draw attention to the offence. Such occurrences were not uncommon during the time I was awaiting trial in Lock Street.

In the remainder of the letter Matotie pleads with responsible elements in the government to 'take drastic action against offending parties'.49 But what Matotie is, in fact, observing in his account is not a set of isolated incidents, but an entrenched culture of violence and abuse in the prison service and amongst criminal investigating officers. Donald Card was a key figure in this set up as a leading CID officer in Duncan Village at this time. $5^{\circ} 50$ The ambitious young Card, whose fluent command of the Xhosa language placed him at the front door of many of those arrested after the 1952 riots, was centrally involved in this culture of violence and intimidation. Many of those interviewed from Duncan Village who were arrested in the police followup operations after November 1952 said they were man-handled by the police and by Donald Card, in particular. One of the state witnesses in the Sister Aidan case of 1953, Afrika Mohasi, openly admitted on camera in 2005 that people were beaten by the police to ensure that they said the 'right thing'. He said that people were 'hit with golf sticks' and would say 'sorry baas, I didn't do it and then (after interrogation) come back the next time and admit to the crime'. ${ }^{51} 51$ By early 1953 Card and the police team had managed to round up the perpetrators. Two were sentenced to death and hanged for Sister Aidan's murder, while another three went to the gallows for murdering the insurance salesman. The killing of Sister Aidan was the more

\footnotetext{
${ }^{48}$ See for example, The Daily Dispatch, 10 November 1952, front page where reports on the riots feature alongside accounts of increased Mau Mau militancy in Kenya. Reports of oathing rituals and the murder of whites in their houses that appeared in the Daily Dispatch frequently in the 1950s heightened fears of all out racial attacks in the region.

${ }^{49}$ J.J. Matotie, Letter to The Daily Dispatch, 5 February 1953.

${ }^{50}$ In his prison diary, Govan Mbeki wrote of similar experiences in Port Elizabeth while incarcerated at the North End 'Rooi Hell' prison. His biographer Colin Bundy reports that: 'Every afternoon he heard beatings from the prisoners returning from work. Sometimes they would bellow. He heard the splattering of leather belts as they fell on a body. "It is intolerable to listen and one shudders to think what effect the type of treatment must have on those who administer it as well as on the recipients .... In the long run it is difficult to see how both can escape being turned into beasts".' Quoted in C. Bundy, Govan Mbeki (Cape Town, Jacana, 2012), p. 107.

${ }^{51}$ Afrika Mohasi interviewed by Koko Qebeyi in 2005, available as unused, archived interview material collected for the Black Cloud documentary, Sikholise Productions, Duncan Village, East London, 2011. For a detailed discussion of these events and their context, see L.J. Bank, Home Spaces, Street Styles: Contesting Power and Identity in a South African City (London, Pluto Press, 2011), pp. 60-67.
} 
gruesome murder as dozens of people were involved at the scene. Some returned after the nun was burnt to mutilate and strip bits of flesh from the charred carcass for muti.52 Card has recalled with regret (on several occasions) that the judge ruled that Sister Aidan was already dead when she was disfigured and therefore that those who did this could not be held responsible for murder.53 Nevertheless, Card emerged as a hero after the case. He was seen as a committed policeman who defended white society, a man of his word who took no nonsense from black criminals and one who was willing to work tirelessly to track down culprits. What is of primary interest to us here is not the outcome of the trial, but the manner in which Donald Card worked the case. Did his approach resemble that of the Sherlock Holmes he is made out to be in Thomas's account? Or was there something distinctly 'extra-legal' about his style of operation? The letter quoted above by ANC youth leader J.J. Matotie suggests that violence and intimidation were part and parcel of the culture of interrogation in the police service at this time. In fact, in a recent interview at his home in East London, Card admitted that the police had to use violence against those they arrested because, as he put it, 'they would not cooperate and just give information voluntarily'.54

One of the theories Card developed was that one or more women attached to the African National Congress Youth League were directly involved in the nun's murder. One of us (Leslie Bank) has interviewed several women who claim they were tortured by Card in his efforts to extract information in 1952-53. Joyce Mohapi (also known as Mavis) was one of thirteen people to stand trial for the nun's murder in 1953. Joyce was a teenager at the time and lived with her mother in the Thulandeville section in the location. This is a transcript of a recent interview in which she, now in her early seventies, recalls the brutal treatment that she and her family suffered at the hands of Card:

Leslie Bank [LB]: What happened up to the time you met Donald Card and got shot [in Bantu Square on 15 November 1952, the day Sister Aidan was murdered]?

Joyce Mohapi [JM]: It was during this meeting that the police came. Very big policemen and soldiers called 'amajoni' told us to disperse within five minutes. We refused and told them we had a meeting. They wanted to know what kind of meeting it was and we told them that it was a church meeting. Donald Card said we were lying, it was an ANC meeting. And so they gave us the final warning but we refused. It is at that time that they began to shoot randomly at everyone and so I got shot on my leg and fell down. A certain man offered to help me, but the police told him that I was now their property so he should leave me to them. We were then thrown into big police vans. All the injured were taken to Frere Hospital [in East London]. The hospital was full of people who had been beaten and shot. Blood was everywhere.

LB: How old were you when you were shot?

\footnotetext{
${ }^{52}$ There was a belief in Duncan Village that the nail scrappings, hair and flesh of white people could make powerful traditional medicines that could be used to strengthen and fortify the body and bring success to those who used it. It appears that the body mutilations were related to this belief, as a form of ritual strengthening, which is also quite common in other parts of southern Africa, see L. White, Speaking with Vampires: Rumour and History in Colonial Africa (Berkeley, California University Press, 2000).

${ }^{53}$ Thomas, Tangling the Lion's Tale, p. 42.

${ }^{54}$ Interview Koko Qebeyi and Donald Card, 25 January 2012, East London.
} 
JM: I think I was 14 , not sure, but was not yet 15 . I was very young but loved the ANC so much. I used to attend political meetings even though my mother did not approve, telling me how unsafe it was. I did not really mind and the day I was shot, Card came to our house...

LB: You say you were thrown into the police van after you were shot and they took you to the hospital ...

JM: Yes, and there were many people there. They say only nine, but we were more than thirty. There was even a lady who had lost her leg from the shooting. We stayed in hospital under police guard and were told that when we got better, we would be taken to jail. I did not know what jail was like, so I told them that I did not care whether I go there or not. I spent the whole year in jail. They went to tell my mother that they would kill me. My mother cried so much because I was the only child she had. Card wanted to beat her up.

LB: What did they want from your mother?

JM: They accused her of being ANC also, but... I was the one who was politically active. I was arrested [in] November and only released in November the following year. But Card used to come to jail, take me away and beat me up. You see, one of my ears is defunct. I was hit by Card. He used an iron pole to assault me and kick me till I wet myself.

LB: Did this happen once?

JM: No, several times. When he came, they would call me saying 'your uncle is here'. When I came from him I would be crying. Even before going with him, I would cry so much. He would take me to a place where he would beat me up.

LB: Where was that?

JM: By the police; at Lloyd,55 inside a cell.

LB: What would happen there?

JM: He would ask me what happened to Sister Aidan. I told him I was not there so I do not know. I was actually in hospital when she was killed. He called me a liar and said I knew the whole story. I denied all those allegations. But the day Card beat me so much and pinned me with his knee on my stomach, I admitted that I had killed her as the pain was unbearable.

LB: Did you admit because he was hitting you?

\footnotetext{
${ }^{55}$ Lloyd was the local name for the location administration offices in Duncan Village which contained police holding cells for pass offenders and petty criminals.
} 
JM: Yes, I did because of the pain. He hit me with an iron bar and kicked me so much that I wet myself and they laughed at me.

\section{LB: Who are 'they'?}

JM: They were two natives. I do not know them. They were there with him but did nothing to me. They were just standing aloof. He is the only one who was hitting me, shouting and swearing at me in isiXhosa saying, 'dirty little bitch'. From there he would put me in the car and back to jail. They did not care about my body that was soaked in blood. I had to wash off the blood on my own or with the assistance of others in jail.

LB: When did you lose your hearing? Was it in this incident when he hit you with an iron bar?

JM: I can't hear on this side. He called me not once or twice, but it must be five times when he took me to beat me up. I only admitted to killing the 'madam' as I thought I was dying because of the pain. As soon as I admitted, he left me and never called me again. On this day, he had strangled me with both hands on my throat and his knee on my stomach. When I was losing my breath from suffocation, I admitted to the killing. 56

In examining the details of Joyce Mohapi's evidence we have discovered inconsistencies in her evidence and that presented to the court in 1953 (in court her age was given as 21 years old while she insists here that she was only 14 or 15 at the time), but overall the evidence is compelling given the detail and especially its consistency with many other cases collected of Card's methods of investigation at this time. 57

As a criminal investigator Card also developed a fearsome reputation during the 1950 . Malcolm Dyani first encountered Card as a nine-year-old boy playing on Petwa Street in the Thulandeville section of the East Bank location in the early 1950s. Dyani recalls Card arriving on the scene in a black Studebaker with another white policeman in the car before disembarking and chasing after a thief. Card backed himself to catch the criminal. Dyani remembers Card firing at the suspect without warning in what was a busy street. 'It was as if he did not care who he hit, he could have killed us.' He shot the man in the leg and dragged him up the hill in cuffs. Dyani had not seen Card before, but never forgot him after that day.

I only came to think about it much later when I realised that this was a man that did not care about black lives. He was a racist, one of those poor whites who felt nothing for harming black people ... In the township people pronounced his name 'Cut' because they could not say Card ... I learnt his name that day, my friends knew he was 'Cut'. People

\footnotetext{
${ }^{56}$ Interview Leslie Bank/Koko Qebeyi-Joyce Mohapi, Mdantsane, 20 April 2011, English and Xhosa. Leslie Bank interviewed Joyce Mohapi on earlier occasions, but only took a full transcript of her evidence against Card in this interview. Her story is corroborated by a report in The Daily Dispatch, 7 February 1953, where her 'confession' of having stabbed Sister Aidan is reported. See also fn.11.

${ }^{57}$ There are similarities, for instance, between the way Card dealt with Mavis Mohapi and his treatment of Nontutu Mosaretsa, the sister of a well-known trained PAC operative in East London in the early 1960s. Card beat Nontutu because he believed that she was receiving and hiding letters received by the local PAC from their high command in Lesotho. Card was determined to get the letters since they outlined local strategy. See Interview, Leslie Bank-Nontutu Mosaretsa, Mdantsane, 20 April 2012 and Interview, Leslie Bank-Cynthia Boshoti (the wife), East London, 10 June 2012.
} 
also called him nobomvu, or red, because of the reddish complexion of his face and his red hair. In his book with Thomas, he says he was affectionately known in the location as mlungisi, meaning 'the one that tries to correct things'. This is untrue, it was never the case. It is a lie. He was never called by that name. We called him 'Cut' or nobomvu - and we knew him as a very violent and dangerous policeman. He was feared for what he could do to a person. 58

Card worked as a detective stationed in East London throughout the 1950s. As the decade wore on his reputation for violence grew and it is clear that by the mid-1950s he was regarded with an almost pathological fear. This fear drew not only on a knowledge of incidents of torture and brutality, his ever-present surveillance of the township streets and his knowledge of people and houses, but also on the idea that he was a 'white witchdoctor', a man who not only spoke fluent Xhosa but could also use his deep knowledge of Xhosa customs to hold an invisible power over his enemies.59 Although there is no space here to explore these claims, it is worth ending this section with the case of Dickson Bazi who was accused of stealing cloth from the Consolidated Textile factory in Chiselhurst on the night of 14 September 1955. In the court case, Bazi explained how he was treated in custody. We quote directly from the report in The Daily Dispatch:

Bazi said that he was taken into custody on September 28 and was released on bail of 25 pounds on October 7, 1955 . . . He was questioned at the Duncan Village charge office and, during the questioning, Sergeant Matthys assaulted him at times for seven days. He was also shocked with an electric cable. The cable was wound around a finger on each hand and he was given a shock. Bazi said that another detective, Sergeant Card, arrived at the Charge-Office at the request of Sergeant Matthys. Sergeant Card administered the electric shocks. A mask was placed over his head and it suffocated him. When he was given the electric shock he was hurled against the wall and received bruises on his right temple... He said that force was used to try to get him to admit to the list of stolen goods. ${ }^{60}$

Card's use of violence was again brought to the attention of the public in September 1956, a few months after the Bazi case, when he became involved in a fight with an alleged criminal from Duncan Village. Edward Bikishe (then 30 years old) was accused of stealing sugar from a city warehouse. Card claimed that he was assaulted by Bikishe, but Bikishe told the court that Detective Sergeant Card assaulted him when he refused to co-operate

\footnotetext{
${ }^{58}$ Interview Leslie Bank-Malcolm Dyani, East London, 29 August 2011. This was the only interview conducted without a research assistant or translator. Dyani later joined the PAC and had other encounters with Card in the 1960s, when he was arrested and interrogated before being sent to Robben Island. He claims that Card gave him 'the washing machine treatment' in one of the police offices in East London. This is when you are handcuffed and suspended between two desks on a pole and spun around. Dyani said that this treatment was commonly used by Card to extract confessions from political activists. He claims that when Card arrested him, he kicked him in the genitals repeatedly with the heel of his boot so aggressively, he recalls, that he almost lost consciousness. Dyani's was one of the cases discussed in an article that appeared in Drum in 1964. Dyani lodged an official complaint in the East London Magistrate's Court on 25 April 1963, alleging that, after being arrested earlier that month, he had been beaten with a rifle butt and jumped on by a policeman. The court records include a district surgeon's report on Dyani's injuries. See 'The "Torture Trials": Drum's Demand for a Full Inquiry', Drum, January 1964. Interviewed in 2011, Dyani identified Card as the primary assailant who 'beat me to within an inch of my life'. Interview, Leslie Bank-Malcolm Dyani, East London, 29 August 2011.

${ }^{59}$ For a full discussion of Donald Card's role as 'white witchdoctor' who admitted to 'throwing bones' in the township and pretended to be possessed by the spirits of ancestors, see L.J. Bank, 'Policing with the Impundulu Bird' (unpublished paper presented at the Anthropology Southern Africa Conference, Stellenbosch, September 2011).

${ }^{60}$ Daily Dispatch, 'Electric Shocks, Beatings', 14 January 1956. Allegations of electric shocks being administered were also made by Aaron Mantsiyose: Interview, Leslie Bank-Aaron Mantsiyose, Mdantsane, 20 March 2012 (and see fn. 82).
} 
by pointing out accomplices during an identification parade organised by the police. Bikishe reported in court that:

Detective Sergeant Card had rushed at him (when he refused to cooperate) and they had fallen to the ground (fighting). He had then caught hold of Sergeant Card's eye. He was subdued and taken to the police station where Sergeant Card had hit him with a tyre lever and had broken his left leg. He was taken to hospital for treatment. ${ }^{61}$

The outcome of this case was that Bikishe was given a suspended sentence for his alleged assault on Card. The judge acknowledged Card's violence in the matter, including the breaking of Bikishe's leg, but nevertheless found Bikishe guilty of stealing sugar, for which he was given several strokes and sent to jail for 15 months with hard labour. ${ }^{62}$ Other similar cases were recorded, which did not appear in the local newspaper, and many of those spoken to had such a fear of Card that they shuddered and stammered when they spoke about him. When asked why they did not report these incidents to the authorities, they said that he was the authority in Duncan Village and they feared what he would do to them and their families. Thus Card was never prosecuted for the violence of which he was accused. ${ }^{63}$ In fact, he was generally congratulated by the state and its officials (such as judges) for his tireless efforts at keeping crime under control in Duncan Village. Asked why they did not take their cases and complaints to the Truth Commission in the late 1990s, the claimants said that it was because the cut-off date for gross human rights violations to be considered by the Commission only began in 1960 .

\section{Reading the TRC Testimonies of Torture, 1962-64}

There is a rich and sophisticated scholarly literature about the difficulties of analysing the testimony of those defined as 'victims' in TRC discourse. 64 The emphasis in this literature has overwhelmingly been on the enormous obstacles in arriving at anything more than the most partial of truths. Silence, erasure, contradiction have been the watchwords in these cautionary analyses. Based in many cases on years of meticulous research, scholars have drawn attention to the constraints of the discourse of the TRC in accommodating different forms of 'truth'; to the complex and potentially distorting impact of trauma upon memory, often citing the literature on the Holocaust for comparative purposes; to the difficulties, if not impossibility, of expressing traumatic experience, such as that of human rights abuse, into accurate verbal forms, forms that in the case of the TRC were ritualised and theatrical; to the multiple levels of translation involved in rendering the traumatic experiences of individuals into transcribed texts in the indigenous languages in which they chose to present them and then into the English, Afrikaans and regional language text translations that provided 'data' to be retrospectively analysed.65 In keeping with the

\footnotetext{
${ }^{61}$ Daily Dispatch, 'Jail and Strokes for Two Natives', 15 September 1956.

${ }^{62}$ Ibid.

${ }^{63}$ Leslie Bank explores how Card also played on people's fears of witches and supernatural forces in the township to assert control and minimise the risk of anyone blowing the whistle on him. See Bank, 'Policing with the Impundulu Bird'.

${ }^{64}$ We are grateful to Nicky Rousseau, Andrew Bank's colleague at UWC, for initially alerting us to the extent of allegations of human rights violations against Donald Card which were made to the TRC.

${ }^{65}$ On the concept of 'truth' see Posel, 'The TRC Report. What Kind of History? What Kind of Truth?'; on traumatic memory see P. Gobodo-Madkikizela, 'Memory and Trauma', in J. Edelstein, Truth and Lies: Stories from the Truth and Reconciliation Commission in South Africa (Johannesburg, Mail \& Guardian Books, 2001), pp. 25- 31; on the complexities of translation see F.C. Ross, Bearing Witness: Women and the Truth and Reconciliation Commission in South Africa (London, Pluto Press, 2003), pp. 2750.
} 
trend in the analysis of oral literature and oral tradition, its emphasis on blurring and fluidity rather than fixity, there has also been interesting analysis of the ways in which TRC testimonies may be read as performed speechacts that draw, in different ways in different cases, on indigenous story-telling traditions. ${ }^{66}$

Yet this emphasis on complexity should not be allowed to relapse into the kind of 'many voices', 'archival enigma' interpretation presented in Prisoner in the Garden. The 'truth' we are in quest of is a particular rather than a general one. It is partly about 'who is Donald Card?', the question posed at the TRC hearing, but it is more specifically about whether we can assert as an historical 'truth', the 'fact' that Donald Card 'tortured' people, using the TRC definition of that term as taken from international law: 'The intentional infliction of severe pain and suffering, whether physical or mental, on a person for the purpose of (1) obtaining from that or another person a confession, or (2) punishing him for an act that he or a third person committed or is suspected of having committed, or (3) intimidating him or a third person, or (4) for any reason based on discrimination of any kind'. 67

Our argument here is that we can. We claim that the evidence put before the TRC against Donald Card is overwhelming and definitive, his own denials and his subsequent life history notwithstanding. Six witnesses provided testimony that they (and in one case their brother) had been tortured by Card between 1962 and 1964. Our interest here is not in the testimonies as narratives amenable to nuanced analysis, but in a more legalistic way as subjective accounts of a series of events which clearly demonstrate a pattern of action on the part of Donald Card. Like other TRC testimonies, these narratives were inflected by trauma and the circumstances of production, but collectively in our view they clearly suggest that Card used torture. We recommend that they be read in the light, firstly, of the evidence of his early history of violence and racial abuse; secondly, of the evidence of his previous uses of torture during the 1950s, and, thirdly, in the more specific context of Card's enhanced role as the head of a crack team of Security Police during the early 1960s. This team was tasked with tracking down the state's political enemies in the newly banned PAC and ANC and included Hans Mynhardt, Coen Scheepers, Baba Goosen and Thompson Tshikila.

All six cases relate to Card's abuse of human rights during the period in which he led this team of interrogators. These are what the narratives describe, in our view, when 'stripped down' to the facts relating to torture. Shumikazi Sara Jako (30 years of age at the time), a PAC supporter, testified that she had been arrested by Card in December 1962 and was beaten up in custody until her genitals bled. She identified Card as the main perpetrator and claimed that he kicked her and threatened to have her raped. ${ }^{68}$ Mfene Simon Yoyo (43), a Poqo (the armed wing of the PAC) activist, testified that he had been beaten by Card and the other policemen under his command at the Cambridge police station in April 1963. He said that he had been hung out of a window in order to try to extract a

\footnotetext{
${ }^{66}$ Ross, Bearing Witness, pp. 27-50; C.M. Cole, Performing South Africa's Truth Commission: Stages of Transition (Bloomington and Indianapolis, Indiana University Press, 2010).

${ }^{67}$ Truth and Reconciliation Commission of South Africa Report, Volume 2, October 1998, p. 189, Note 8.

${ }^{68}$ Shumikazi Sara Jako, TRC Hearing, Mdantsane, 12 June 1997, Transcript, pp. 9-10. Note the similarities in the treatment of Jako and that of Mavis Mohapi described. Similar evidence was collected from Nontutu Bishoti by Leslie Bank in East London, 20 April 2012.
} 
confession of political involvement. ${ }^{9}$ Makhi Boyi (24), also linked to the PAC, said that on 9 April 1963 he was arrested and taken to the Ncora River where he was handcuffed to a pole and where Card threatened to kill him if he did not tell the truth. He was later beaten, kicked and punched by a group of policemen including Card. Boyi replied that the reason why he could so clearly remember Card's name and not those of other perpetrators was because 'he [Card] was known for torturing people'.70 $\mathrm{He}$ said that he had been tortured over a period of two years. Daniel Paulus Nongena (37), a Poqo activist, testified that he too had been beaten and punched by Card while imprisoned in East London before being sentenced to 12 years on Robben Island in October 1963. Zweliyazuza Gwentshe testified that his brother Mzimkulu, had been assaulted by Card at Fort Glamorgan in 1963 and by other policemen in Cape Town in 1964 before being sentenced to five years in prison. It was partly as a result of the head injuries inflicted by his torturers that he spent most of his sentence in Valkenberg Mental Hospital in Cape Town. ${ }^{71}$

Mncedisi Mapela provided the most detailed narrative of being tortured by Donald Card:

The one day I was taken from work at three o'clock . . Donald Card, Mbombo [Mynhardt] $7^{2}$ and Tshikila were the three policemen. We went to Fleet Street [in East London] . . . Donald Card punched me. I got a bit dizzy. That is when they got the chance to hand-cuff me. They put me on top of a table that was as high as this one, [a] very thick table, an antique. Card, Donald held me at the feet and another one from the top. Tshikila put his knee on my stomach and started choking me on the neck. He hit me against the table with the back of my head. I fell on the floor, I lost consciousness. When I regained consciousness I tried to get up, but I could not . . . [F]rom three o'clock to eleven o'clock they were torturing me. They would put me on the table and torture me. If you looked on my neck you would think that a dog had beaten [bitten?] me . . . My face was swollen, my ears bleeding, my mouth. I was bleeding everywhere . . . They said they were going to kill me if I did not divulge.73

He too claims to have been hung from a window. After his release he recalls the conversations of his comrades and his wife who thought it unlikely that he would survive. The torture he experienced caused lasting damage to his kidneys and stomach. He asked the Commission if they could assist him with his medical costs. 74

One of the seemingly confusing aspects of the claims made against Donald Card related to whether the accusations against him were as a result of his fearful reputation, or due to

\footnotetext{
${ }^{69}$ Mfene Simon Yoyo, TRC Hearing, Queenstown, 23 July 1996, Transcript, p. 3.

${ }^{70}$ Makhi Boyi and Daniel Paulus Nongena, TRC Hearing, King William’s Town, 14 May 1997, Transcript, pp. 1-2, 5.

${ }^{71}$ Zweliyazuza Gwentsche, TRC Hearing, Mdantsane, 11 June 1997, Transcript, p. 6. A summary of each of these cases, as well as that of Mapela described below, is given in TRC Report, Vol. 7 Victim Findings: Summaries, Part 2, pp. 38-39, 143-4, 166; Part 3, p. 318, Part 4, p. 675, Part 5, p. 895. A PAC activist in East London also spoke of the case of Mountain Langben, a PAC activist from Duncan Village who was sentenced to three years on Robben Island in 1963, but was said to have been so severely beaten by Card and his team before arrival that he died shortly after arrival on the island as a result of his injuries. Mongemeli Platyi was one of those who nursed him on arrival and states clearly that it was the work of Card. Interview Leslie Bank-Mongemeli Platyi, 15 March 2012.

${ }^{72}$ Joe Jordan testified at the TRC hearing in Duncan Village on 23 September 1996 that 'Minard [Mynhardt] was one of them [the security police] who was known as Mbombo here in Duncan Village'. TRC Report, Vol. 6 Amnesty.

${ }^{73}$ Mncedisi Mapela, TRC Hearing, Mdantsane, 13 June 1997, Transcript, pp. 1-3, 6.

${ }^{74}$ Ibid.
} 
his actual presence at interrogations where abuse was alleged to have occurred. Thomas goes to considerable lengths to try to defend Card by claiming that assertions about his abusive past were often stated, but never unequivocally proven. He implies that they were fabrications. But Card's violent and abusive reputation was not made from thin air. It was earned through persistent practice that dated back to 1953. In the later period covered by the TRC, additional oral evidence simply confirms that Card used what had by now become a standard procedure in his interrogation sessions. 75 His command of the Xhosa language, his familiarity with the cultural context and his ability to manipulate local fears and belief systems contributed to his effectiveness as a policeman, but it was his physical strength and domination of his subjects that was his most potent weapon. According to the testimonies presented to the TRC, and those additional accounts we have gathered relating to his police work during the 1950 os and the early 1960s, Card wanted to make his suspects 'sing' and, if they proved to be stubborn, he was prepared to beat and torture them until they did. He would usually start by cuffing the victim's hands behind his back, if that had not been done already, and then would beat them around the body and the head. One version of the cuffing and beating technique was known as iviri or 'the wheel' where Card and his associates handcuffed the victims' wrists and ankles and rotated them around using a pole suspended between two desks or chairs, creating incredible pain on their cuffed joints which carried the body weight. On other occasions the accused would be asked to strip down. There are instances where victims testify that they were made to place their private parts in the desk drawer which was then repeatedly slammed shut until the accused fainted from the pain. ${ }^{7}$ In other cases we collected Card was said to have asked his victims to strip down and then inserted needle-like objects (ingacu), similar to the pins used by women to pin up their hair, into the testicles of his victims. Another way Card was said to have rendered his victims unconscious was by banging their head against the wall rhythmically and repeatedly until they passed out. Card did not, of course, act alone in these interrogations. He had a loyal team, but he was undoubtedly the lynch-pin, the interrogator in chief who knew exactly what he was looking for. His handlers softened up his victims before he moved in to finish the job.

Our own reading of Card's modus operandi is that, whilst he initially had acted as a lone ranger covering his beat in Duncan Village, he leaned much more heavily on his team as he was drawn into more complex political cases in the 1960s. The evidence suggests that Card was concerned with impressing his superiors by proving that he could deliver prosecutions and convictions. He was also allegedly a master at manipulating evidence to make sure he secured convictions in court, and was mightily proud, as his narratives in the Thomas book show, of how many men he sent to the gallows. ${ }^{77}$ But, despite his

\footnotetext{
${ }^{75}$ Interview Leslie Bank-Monde Mqonqwana, East London, 1 August 2010; Leslie Bank-Tamsanqa Nelson Dick, East London, 1 August 2010; Leslie Bank-Matthew Makalima, Alice, 10 August 2010; Interview Leslie BankGideon Valakazi, East London, 20 July 2012; Interview Leslie Bank-Sidney Seli, East London, 20 July 2012; Interview Leslie Bank-Henry Fazzie, East London, 14 October 2010; Vuyani Mngaza, Middledrift, 20 and 30 April 2012.

${ }^{76}$ Interview Leslie Bank-Monde Mqonqwana, East London, 1 August 2010; Interview Leslie Bank-Tamsanqa Nelson Dick, East London, 1 August 2010; Interview Leslie Bank-Matthew Makalima, Alice, 10 August 2010; Interview Leslie Bank-Frank Meni, 11 March 2012; Leslie Bank-Mongemeli Platyi, 15 March 2012; Leslie Bank-Vuyani Mngaza, 20 June 2012.

${ }^{77}$ Interview Leslie Bank-Tamsanqa Nelson Dick, East London, 1 August 2010, also Leslie Bank-Gideon Valakazi 20 July 2012. Dick claimed that Card had planted evidence in the sabotage case in which he was convicted and that this was uncovered by the judge who ruled that one of the accused could go free because Card's evidence was obviously fabricated. Dicks said that it was well known in liberation movement circles that Card would doctor evidence wherever he could to get the results he wanted through the justice system.
} 
success, we learnt that Card was not well liked by other local policemen and was involved in several fights and altercations with other policemen in East London. 78 The impression we get is that Card was always hungry for recognition and acknowledgement from his superiors (and the public) and enjoyed the loyalty of his team but was disliked by many rank and file officers in the service. 79

\section{Further Testimonies of Torture in 1963}

To illustrate Card's reputation as an interrogator, it is worth considering the case of Matthew Makalima, an ANC activist from Port Elizabeth who went into exile and was intercepted by the Rhodesian police in Bulawayo, together with other cadres from the Eastern Cape, before being handed over to the South African police in Pretoria for interrogation. Makalima remembers the journey from Bulawayo to Pretoria very well and the rough handling they received at the hands of the Rhodesian and South African police. He also recalls how informers were placed in the group to try to extract information. When this strategy failed, the Eastern Cape men were handed over to Card and his team who travelled up in January 1963 specifically to interrogate the captives. In his own narrative of the events, Card suggests that he managed to extract all the information required by playing the cadres off against each other. ${ }^{80}$ Makalima acknowledged that this strategy was used and that Card did secure some information this way. But in the end, Card and his team would seem also to have followed more gruelling and violent interrogation methods as well. Makalima claims that he was first roughed up by Card's handlers and then badly beaten by Card himself. He recalls that he lost consciousness several times while Card was beating him, smashing his head against the wall, and woke up in a cold cell, battered and bruised, lying in his own faeces and urine. Card had such a reputation for violence and torture, he said, that other activists 'even wet their pants at the thought of him arriving in the interrogation room' ${ }^{81}$

This account of Makalima's capture and interrogation is significant because it reveals Card's growing reputation within the township by the early 1960s. One of Card's common refrains when accused of human rights violations has been to point to the fact that he only joined the Security Police in 1964. However, it seems likely that he was drawn into political cases after the formation of the Pan Africanist Congress in 1959 and the shift to armed struggle. At this time Card was asked to head up a local sabotage unit where he was given power to arrest and interrogate people suspected of plotting against the state. In his position he could also conduct spot interrogations at any police station in the city or region, making nonsense of his repeated claims that he could not be held responsible for

\footnotetext{
${ }_{78}^{78}$ Interview Leslie Bank-Malcolm Dyani, East London, 29 August 2011.

${ }^{79}$ Several of the liberation movement veterans we spoke to emphasised this point, saying that others were envious of Card's success in getting convictions and irritated by his arrogance. Malcolm Dyani told us specifically that Card was involved in several fights and arguments with other local policemen. Interview Leslie Bank-Malcolm Dyani, East London, 29 August 2011.

${ }^{80}$ Card gives his own version of his strategy of interrogation, suggesting that it revolved around getting the cadres to overhear each other's evidence and then spill the beans because they felt that the game was up. See Thomas, Tangling the Lion's Tale, pp. 12527. This is not how Makalima remembers events. He acknowledges that Card used these tricks, but says that it did not end there. Card was not satisfied until he had 'all the information'. Makalima claims he was tortured and beaten to within an inch of his life. Card's defence in the Thomas book is that he seldom, if ever, used violence because he was such a skilled manipulator of information and informants. He implies that he did not need to beat people because he was an expert at making them talk. Here his claims are directly at odds with the testimony of Makalima and others.

${ }^{81}$ Interview Leslie Bank-Matthew Makalima, Alice, 10 April 2011. This was confirmed by other activists, including Monde Mqonqwana.
} 
interrogations, such as that of Simon Yoyo in 1962, that were not conducted at his Fleet Street offices. ${ }^{82}$

In 1963 Card's name appeared on an ANC hit list and there was much talk of the need to 'take him out' amongst PAC activists as well. Mongemeli Platyi, a trained PAC guerrilla from Duncan Village, remembers planning an ambush for Card at a bridge near the hostels in Duncan Village. This attempt on Card's life failed because the firing pin on Platyi's gun jammed. 83 These were nervous times for Donald Card. His profile and popularity as a crack policeman had drawn himaway from East Bank as he became involved in political cases in places like Port Elizabeth, Alice and Pondoland after 1960 and, with distance and political re-organisation, his power, presence and influence in Duncan Village diminished. Card was no longer in full control of his home turf, East Bank, and his own narrative of his personal power, his claims of 'having an informer on every street' and of holding the township in the palm of his hand, no longer rang true. He was also weakened by the invisibility of the underground structures (a consequence of the PAC's reorganisation after 1960 into small, cell structures), the circulation of guns in the township and his lack of knowledge of exactly what the ANC and the PAC were plotting, where and when. This was a period, we argue, in which Card started to doubt his safety and capacity for control, a time when his insider networks let him down and he came to rely more on force to get the information he needed.

In the Thomas book, Card represents the move from Duncan Village into a broader political scene as the seamless progression of the master detective in total control of his world. This is definitely not the impression we got from interviewing political activists from that period. There was a sense of desperation in Card's actions in the early $1960 \mathrm{~s}$ and constant and recursive recourse to violence as he clambered for leads and evidence. One of the key stories in his book concerns the way in which he single-handedly thwarted a plan by the PAC to attack whites in East London in April 1963. He recalls how he infiltrated the PAC inner group and insinuated himself amongst them in the bush with his face painted black, waiting to pounce and arrest the terrorists. Other accounts of the sequence of events suggest that Card was ignorant of the planned attack until the last minute and that he was hiding in the bushes, not amongst the Poqo cadres, but with other policemen similarly camouflaged. ${ }^{84}$ Malcolm Dyani, who was second in charge of the armed Poqo group that day, claims that:

\footnotetext{
${ }^{82}$ Like Simon Yoyo, Aaron Mantsiyose was another young man from East Bank whom Card and Tshikila suspected of being political involved who recalled how he had been beaten up by Card and Tshikila and suspended from the upstairs window at the Cambridge Police station. His evidence, together with that of many others, confirms that Card was frequently conducting interrogations and torture session at the Cambridge Police Station by the early 1960s. He was using this facility long before he formally switched to the Security Police in 1964. Interview Leslie Bank-Aaron Mantsiyose, Mdantsane, 17 April 2012.

${ }^{83}$ Interview Leslie Bank-Mongemeli Platyi, Mdantsane, 15 March 2012. Platyi was another witness who alleged serious abuse on a different occasion by Card and other policemen. Drum (January 1964) reported that a medical examination on 4 June 1963 had confirmed an eye injury consistent with having been caused by a blow (Exhibit 'W', The State vs China Lwana and 25 Others, Butterworth Circuit Court, 25 Oct. 1963, 1/5 Strafafwagtende Nr. 2381/63 Mongemile Pladji [sic]). In two interviews in 2011, Platyi identified Card as the assailant. Interview, Leslie Bank - Mongemeli Platyi, Mdantsane, 8 and 15 March 2011.

${ }^{84}$ Card was skilled at manipulating evidence to ensure convictions. This meant that he would spend more time in court than other policemen and often received acknowledgement from judges for his role in capturing criminals or political activists. Card was always keen to take the limelight and to underplay the role of his colleagues in investigations and arrests. His image of his own importance should not replace the idea that the police worked as a collective unit against the PAC and ANC.
} 
Card was not amongst us at all. He was hiding in the bushes some distance away. There were many policemen with him there waiting to break up the meeting and arrest us. Card was certainly not alone ... When they attacked us, he was the one who trapped me and beat me to the ground. I was not a good runner. It was Card who then beat me to within an inch of my life. He started kicking me in the crotch . . . not with that part of the foot [pointing to the top of his foot], but with this part [pointing to his heel]. He kicked me like he wanted to kill me. He then drove his steel rifle butt into my body. He did it over and over again ... I thought I would die. It was because I was so young, so light and weightless, that I survived. 85

The stories of those who were arrested in the follow-up operations after the failed Poqo attack of April 1963 reveal a litany of human rights abuses and the routine use of torture by Card and his colleagues. ${ }^{86}$ There were men amongst the Poqo activists who were simply not prepared to divulge information about their organisation, their plans and their leadership. In the months between April, when the planned attack was thwarted, and October when the case against the PAC men was heard in the Butterworth magistrate's court, 87 many hours of interrogation and torture were undertaken by Card and his trusted colleagues in the force, Coen Scheepers, Hans Mynhardt and Thompson Tshikila. All of these men had entered the bush with Card on the night of the planned attack disguised as Poqo operatives. The drama of this joint operation had strengthened the bond between them. They had risked their lives together on that night and now worked together to bring the culprits to justice. One by one they rounded up the Poqo activists who were in the forests and took the stubborn ones to Card's special interrogation room at the Fleet Street station. The Poqo detainees remember that the walls of the room were covered with reed

\footnotetext{
${ }^{85}$ Interview Leslie Bank-Malcolm Dyani, East London, 29 August 2011. Leslie Bank has also collected a detailed account of the police clampdown on the ANC in DuncanVillage in 1963 and the role of Card in the interrogation of activists like Monde Mqonqwana. The style of interrogation was very similar to that described by Makalima. Card's team pummelled Mqonqwana, before being joined by the chief interrogator, Donald Card who then beat Mqonqwana, moving him in and out of consciousness until he eventually broke.

${ }^{86}$ In assembling the evidence presented here we would like to extend a special word of thanks to Ndiphiwe Mkuze, a Fort Hare student from Mdantsane for the many days and weeks he spent with Leslie Bank tracking down former PAC cadres in East London, King William's Town and Alice. He sat in on many interviews, especially of PAC activist, offering translations and interpretations of the evidence presented.

${ }^{87}$ Although space does not permit us to present or examine the evidence here, we have found contemporary documentary evidence from court records of five further victims of torture who explicitly identified Donald Card as their primary assailant. In one case, tried in November 1963 in the Butterworth Circuit Court, five witnesses testified that they had been tortured by Card, namely Mpandlana John Menzeleli, Kolekile Welcome Fini,

Bulwana Mbali, Henry Trouwers and Mtutuzeli Cecil Mgoqi. In all cases, their testimony was presented in summary form to Card by their defence attorney, Mr Titterton (he denied the allegations), and then in more detail by themselves in person at the trial. The last-named brought an official case of assault against Card and pointed him out as the assailant in a police identity parade; he stuck to his account in court under cross-examination by Card's defence attorney (Western Cape Archives and Records Repository (Cape Town), 1/40 Grahamstown Supreme Court, 1/2/1/35, Butterworth Circuit Court, Criminal Case No. 388 of 1963, The State vs Mtutuzeli Cecil Mgoqi and nine others, 12-16 and 18 November 1963). What is striking in this case is the absolute certainty with which Mgoqi identified Card in court. '[Card's attorney Mr D'Arcy] Are you sure that Sergeant Card was one of the people that did assault you? - [Mgoqi] Yes. [D'Arcy] And Sergeant Card is the man sitting here next to me? - [Mgoqi] Yes. [D'Arcy] He is the man who slapped you in the face? - [Mgoqi] Yes. [D'Arcy] Are you sure of that? [Mgoqi] I am certain ... ' (Accused No. 1, p. 192). In a second case tried in the same court in October 1963, five witnesses testified that they had been tortured by members of the East London police force, namely Linda Bikitsha, Malcolm Dyani, Bulwana Mbali, Mplandlana Menzeleleli and Mongemile Pladji [sic]. (Western Cape Archives and Records Repository (Cape Town), 1/40 Grahamstown Supreme Court, 1/2/1/35, Butterworth Circuit Court, Criminal Case No. 387 of 1963, The State vs China Lwana and twenty-five others, 25

October 1963). Four of them were found by the district surgeon to have wounds consistent with this testimony and in two cases contemporary oral interview evidence identified Donald Card as the man responsible for these wounds. For the medical evidence, see Western Cape Archives and Records Repository (Cape Town), 1/40 Grahamstown Supreme Court, 1/2/1/35, Butterworth Circuit Court, Criminal Case No. 387 of 1963, The State vs China Lwana and twenty-five others, 25 October 1963, Exhibit S, 'Doctor's report' dated 25 April 1963, and Exhibit 'W', Strafafwagtende Nr. 2381/63 Mongemile Pladji [sic]. For the contemporary oral evidence, see Interview Leslie Bank-Malcolm Dyani, East London, 29 August 2011 and Interview Leslie Bank/Ndimphiwe Mkuzo-Mongemeli Platyi, Mdantsane, 15 and 18 March 2012.
} 
mats with various pieces of torture equipment, such as knuckle-dusters, batons, and the like. ${ }^{8}$ Card was 'the boss of this place', the interrogator-in-chief. He led the sessions, which usually started with them being roughed up and taken to the cell. Later, in the presence of three or four policemen, a wet towel would be wrapped around their necks, throttling them and twisting their necks from side to side. In the descriptions collected of this technique, the activists said that their eyes would turn red and swell, while their heads became numb as they choked and blacked out.

Card is again explicitly identified here as the one who smashed their heads against the concrete wall, forcing them in and out of consciousness while questioning them in Xhosa. Hans Mynhardt, who had crawled through the forests with Card in disguise, ${ }^{89}$ now worked with him to pummel the bodies of these Poqo men. Amongst the techniques used by Card and Mynhardt was the insertion of needles into the testicles of the accused. The men said that Card would insert the needles and that he was the leader. $9^{\circ}$ The violence and torture perpetrated by Card and his colleagues in 1963 was not restricted to those who were in the forest. His team also pursued those who aided or abetted the Poqo operatives in the township, including sisters, girlfriends and mothers. ${ }^{91}$

What is certain, from the weight of evidence that we have assembled here, is that Donald Card was not a normal - albeit highly successful - law-abiding apartheid policeman as he and others have been wont to insist. His actions and techniques went beyond what was formally permitted by law - torture and the physical abuse was illegal, even under apartheid. The evidence points to a deeply entrenched culture of violence and torture in the police force in East London, which appears to have been increasingly condoned by the authorities as the 1950s wore on. Victims of police abuse and violence could, of course, lodge cases against the state - and some did - but very few of these cases succeeded, especially given the political mood of the white judges in the Eastern Cape who treated Card like a hero as the Bikishe case cited above well illustrates. Our argument is not that Card was alone in his actions, but rather that he played an important role in entrenching a racist culture of violence in the operations of the Eastern Cape police and security services, one in which torture and human rights abuses were normalised. ${ }^{2}$ It is this culture that allows us to understand how someone like Steve Biko was killed in police custody in the Eastern Cape in 1977. It was not the excesses of one racist policeman that

\footnotetext{
${ }^{88}$ A wider point is made in the vivid description of 'the torture chamber' of the fictional policeman 'David Conrad', in Livingstone Mqotsi's novel, House of Bondage (London, Karnack, 1990), p. 21. Mqotsi's account was based on his experience of working as one of the lawyers defending those activists charged in the two Butterworth Circuit Court 'Torture trials' of October and November 1963. See previous footnote.

${ }^{89}$ See Thomas, Tangling the Lion's Tale, pp 101-104.

90 See Interviews Leslie Bank-Mongemeli Platyi, Mdantsane, 15 and 18 March 2012; Interview Leslie Bank-Frank Meni, Mdantsane, 17 March 2012.

${ }^{91}$ The information presented in this paragraph has been extracted from interviews with former Poqo operatives undertaken by Leslie Bank in and around Mdantsane in March 2012. See especially Interviews Leslie Bank and Mongemeli Platyi, Mdantsane, 15 and 18 March 2012, also Interview Leslie Bank and Frank Meni, Mdantsane, 17 March 2012; Interview Leslie Bank and Hamilton Keke, 14 March 2012. Interviews with women include Leslie Bank interview with Mama Kettledas and family members, with Nontutu Bishoti, the sister of a leading PAC activists in East London.

${ }_{92}$ In his TRC evidence, Card denied that he could have been involved in torture at the Cambridge police station because his offices were at Fleet Street. It is true that he mainly used Fleet Street where he had his 'special room', but he also moved his victims between stations. His victims say he increasingly worked at Cambridge after the police in East London acquired a torture robot with mechanical arms, known as 'shorty'. The arrival of 'shorty' in the early 1960s meant that a lot more interrogation was done at the Cambridge station. Card used the two stations interchangeably after this. Interviews Leslie Bank-Nontutu Bishoti, 16 March 2012, Leslie Bank- Mongemeli Platyi, Mdantsane, 15 and 18 March 2012, Leslie Bank-Frank Meni, Mdantsane, 17 March 2012.
} 
killed Biko in a Port Elizabeth jail but a systemic and deeply engrained culture of violence, a culture in which Donald Card played a part in the two decades prior to the Biko tragedy.

\section{Conclusion}

Our case then is that, whatever the difficulties of weighing up the different kinds of 'truths' under investigation by the TRC, there is an abundance of evidence that Donald Card was guilty of gross human rights abuses during the 1950s and 1960s in East London. We have sought to read the narratives of torture - widely available in oral testimony and documentary record-against the backdrop of his personal history of violence and assumption of a domineering and brutal form of white masculine identity. The opening section of the article made the argument that recent scholarship has been complicit in offering a sanitised version of his life history, partly because he had returned the Mandela notebooks. But the silence is wider than that, certainly not confined to the lack of curiosity of a few scholars. One of the local interpretations for the failure to investigate the Card allegations more fully, especially given that such allegations continue to be made in the Daily Dispatch by members of Eastern Cape communities and are still vehemently denied by Card, is that such investigations would not have been in the interests of the ruling party. It would have, firstly, revealed the political dominance of the PAC as the most popular liberation movement in the Eastern Cape during the 1960s, which won widespread support for the radical Africanist politics it advocated. Secondly, it would have exposed the limitation of the TRC compromise and widespread disenchantment in the province with the nature of the political settlement.93

Card's own narrative of his policing style, most clearly articulated in the Thomas book, is that of a righteouswarrior and masterful detective enforcing the country's law and protecting the status quo at a time of political turmoil and insurrection in East London and the Eastern Cape. This carefully crafted version of his life and police work continues to be propagated in the letter pages of The Daily Dispatch in East London, where Card remains an active voice on issues regarding local government and national politics. In making critical points about local politics, Card is sometimes challenged about the dark history of his activities in the apartheid security police force. He always responds with self-righteous indignation, saying that his 'record is clean' and that he has been 'cleared' by the TRC. The TRC Report is much more ambiguous than this would suggest, however, as we have shown. $9494 \mathrm{He}$ insists that he has done nothing wrong and that he was simply doing his job as a policeman working within the laws of the day. 95

In March 2012, Card criticised the new city manager in Buffalo City in a letter to the newspaper. A few days later a response was received asking what right Card had to criticize when he was a torturer. Card responded (again) by saying that his record was

\footnotetext{
${ }^{93}$ Pholo Mangqaqwana, a former Poqo activist, for example, who also claimed abuse during interrogation by Card, wondered why his evidence was not seen as sufficiently compelling to be heard by the TRC and why only Yoyo's case was selected after the Commission visited the PAC in Queenstown. He suspects that one of the reasons might have been that his submission was 'too radical' for the TRC and was not sufficiently conciliatory in tone for that project. He suggests that the process of 'silence by selection' shut out certain versions of the truth. Interview Leslie Bank/Ndimphiwe Kuzo-Pholo Mangqaqwana, Queenstown, 4 December 2012.

${ }^{94}$ This 'clearance' applied only to his formal amnesty application and the Commission's willingness to record his denials. Against this we must set the acceptance of the victim testimony of all six accusers presented in summary form in the TRC Report, Volume 7.

${ }^{95}$ The Daily Dispatch, 2 March 2012.
} 
clean and threatened to sue the author for making the suggestion, saying that if he thought his accuser had money he would 'take him to court'. ${ }^{6} \mathrm{~A}$ few weeks later another letter appeared in the Dispatch from a person working for tourism on a liberation heritage trail in East London. The writer stated that he had met an 83-year-old man who claimed that Card was a torturer. 97 Card responded by stating that he had done nothing wrong, that he was innocent of all charges and that he had simply been a law abiding apartheid cop. 98

In the townships of East London and the rural areas of the Eastern Cape where a different truth about Card's policing methods is well known, questions are asked about why he always seems to have the last word and why no serious attempt has ever been made to document the full extent of his wrong doing. Indeed, in assembling this case, we have been mindful of our responsibility as scholars to heed the call of those in the Eastern Cape, those victims of apartheid who say 'enough is enough, the truth about Donald Card should finally be made public'.

\footnotetext{
${ }^{96}$ Ibid.

${ }^{97}$ The Daily Dispatch, 16 March 2012.

${ }^{98}$ The Daily Dispatch, 19 March 2012.
} 